\title{
Maxillary Sinus Cancer TNM Finding v6
}

National Cancer Institute

\section{Source}

National Cancer Institute. Maxillary Sinus Cancer TNM Finding v6. NCI Thesaurus. Code C64402.

A finding about one or more characteristics of maxillary sinus cancer, following the rules of the TNM AJCC v6 classification system. 